\title{
SALE SUBJECT TO A CONDITION IN ISLAMIC LAW: A JURISTIC ANALYSIS
}

\author{
Md. Habibur Rahman ${ }^{1}$ \\ Muhammad Amanullah ${ }^{2}$
}

\begin{abstract}
In the contemporary period, there is hardly any transaction that is detached from its respective terms and conditions. This study aims to explore and analyze the issue of sale subject to a condition from the viewpoints of various schools of Islamic law. This study was accomplished through the scrutiny of the related primary sources of these schools. The researchers have found that the judgment of a sale with conditions is subject to the status of the related condition itself. Any condition that conforms to the requirements of the contract and customs is valid; otherwise it is invalid. Similarly, the study posits that the ruling of the contemporary transaction with terms and conditions is subject to the status of relevant conditions. If the condition is consistent with the contract and Shariah, it is valid and effective. Any condition that contradicts the requisites of the contract and Shariah are invalid and accordingly invalidate the transaction as well.
\end{abstract}

Keywords: sale, condition, Islamic Law

\footnotetext{
1 Ph.D Candidate, Department of Fiqh and Usul al-Fiqh, International Islamic University Malaysia, hrnizamee@yahoo.com

2 Professor, Department of Fiqh and Usul al-Fiqh, International Islamic University Malaysia, amanullah@iium.edu.my
} 


\section{INTRODUCTION}

A contract is an official agreement between parties. By making a contract, one either achieves rights or incurs obligations and liabilities. Essentially a contract is concluded mutually on the terms and conditions in order to achieve everyone's goal thereof, with Islamic Law safeguarding their interests. There are transactions that may be simply concluded verbally without noteworthy terms and conditions, while there are transactions that may be formal, notarized, and registered with a government agency, all subject to numerous terms and conditions.

In fact, conditions in transactions are intended to regulate them in their operation, so that none of the contracting parties suffers from injustice. It is the key concern of Islamic law of contract that none of the parties shall suffer from any undue burden (as much as possible). Thus, the condition normally complements the cause and gives it its full effect. In other words, the legal consequences of a contract are not fully realized without the fulfillment of its necessary conditions. ${ }^{3}$

\section{MEANING AND DEFINITION OF CONDITION}

The Arabic word for condition is shart, with the plural being either shurut or sharā'it. Literally, it means 'obligation and commitment'. It also refers to a sign or symptom. Moreover, it refers to something which is contingent on something else for its existence, yet it is not included in the essence, but a complementary part thereof. Furthermore, the absence of a shart necessitates the absence of the rule, but its presence does not necessarily manifest said rule. ${ }^{4}$ For example, the condition of purity for prayer, whereby it would be invalid without purity. However, if one obtains purity it does not necessitate that he/she must start praying. Shart also means the obligation of a contracting party towards another against a benefit he/she enjoys in the contract, and in order to be effective such an obligation must be associated with the contract. ${ }^{5}$

According to the Hanafi school, the absolute condition (shart mahd) is something that the motive of the ruling ( 'illah) depends upon. So, shart relates

\footnotetext{
3 Abdurrahman Raden Aji Haqqi, The Philosophy of Islamic Law of Transactions (Kuala Lumpur: CERT Publications, 2009), 70.

4 'Abd al-Karīm Zaydān, al-Wajīz fì Ușūl al-Fiqh (Beirūt: Mu'assasat al-Risālah, 1997), 59.

5 Manșūr Ibn Yūnus al-Bahūtī, Kashshāf al-Qinā' 'an Matan al-Iqnā', vol. 3 (Beirūt: Dār al-Kutub al-'Ilmiyyah, 1997), 217.
} 
to the ruling in terms of its presence or absence, yet it does not necessitate the ruling; unlike the 'illah which obligates the ruling. Thus, in the Hanafi school shart means a 'sign'. So, in the case of punishment ( $h u d \bar{u} d$ ), being married is a condition (shart) for stoning (rajm), not the reason or motive for it. It might be said: if shart does not contradict the 'illah, it gives the sense of 'illah. If it contradicts 'illah, then if it happens earlier it gives the sense of 'illah, while if it happens with 'illah or later, it is then an absolute condition (shart mahd). The absolute condition could be the real factor on which the fact or the legal ruling depends, for without the ruling would not be valid at all. For example, the condition of needing a witness for marriage. Also, a condition may be improvised, such as when someone puts a conditional clause in his action and the like. ${ }^{6}$

Al-Qarāfì from the Mālikī School defines the shart as something whose absence requires the absence of a ruling, but its presence does not necessarily require either the presence or absence of a ruling. ${ }^{7}$ Al-Shawkānī of the Shāfi 'ī School says that shart is the ruling on attributes, which is a condition for such a ruling to begin with. The essence of shart is that its absence requires the absence of a ruling, or the absence of the reason due to a motive that is inconsistent with the motive of the ruling and reason. For example, the elapsing of one year is the condition for zakāh to be obligatory, so in the absence of this condition the obligatory nature of the ruling would also be absent. In the case of adultery, marriage is the condition for stoning, so its absence requires the absence of such a ruling. ${ }^{8}$

Abū al-Khațāāb al-Hanbalī defines shart as something whereby the ruling exists and disappears without cause. For example, in the case of adultery, being married is the condition for stoning, while not being married would not obligate stoning, despite the same act having been performed (fornication). ${ }^{9}$ Al-Zarkashī says: shart means 'sign'. So, it is called ashrāt al-sā' 'ah, i.e. the symptoms of the Day of Resurrection. Shart is something whose absence obligates the absence of something dependent on it. ${ }^{10}$

$6 \quad$ Abū Bakr al-Sarakhsī, Ușūl al-Sarakhsī, vol. 2 (Beirūt: Dār al-Kutub al-'Ilmiyyah, 2005), 320; 'Ubayd Allāh Ibn Mas'ūd al-Hanafī, al-Taw dīh li Matn al-Tanqīh fì Ușūl al-Fiqh, vol. 1 (Beirūt: Dār al-Kutub al-'Ilmiyyah, n.d.), 145.

7 Shihāb al-Dīn al-Qarāfī, Sharh Tanqīh al-Fuṣūl (Cairo: Maktabat al-Kulliyyāt alAzhariyyah, 1993), 261.

8 Muḥammad Ibn 'Alī al-Shawkānī, Irshād al-Fuḥūl ilā Tahqūq al-Haqq min 'Ilm al-Ușūl, vol. 1 (Beirūt: Dār al-Kutub al-'Ilmiyyah, 1999), 53.

9 Abū al-Khațāa Maḥūz al-Hanbalī, al-Tamhìd fì Ușūl al-Fiqh, vol. 1 (Beirūt: Mu'assasat al-Rayyān, 2000), 68.

10 Badr al-Dīn al-Zarkashī, al-Baḥr al-Muḥịt fì Uṣūl al-Fiqh, vol. 1 (Beirūt: Dār alKutub al-'Ilmiyyah, 2000), 248. 
So, all the prominent Schools of Islamic law have agreed on the essence of the shart, i.e. it is an attribute that has an effect on the ruling since its absence necessitates the absence of the ruling, though its presence does not necessitate either the absence or presence of the ruling.

It should be noted that shart is among the declaratory addresses by Allah (khitāab al-wad ). The scholars of Ușull al-Fiqh classified the addresses of Allah into two categories: First, the obligatory addresses (khițāb al-shar) which encompasses the rulings of mandatory, recommended, prohibited, not recommended, and permissible activities; while the second are the declaratory addresses (khitāb al-wad ), which refers to the addresses of Allah making one thing as the reason, condition, or hindrance for another thing. For example, a minimum amount stipulated (nișāb) is the reason, and passing one year (hawl) is the condition for zakāh to be obligatory. ${ }^{11}$

It is noteworthy here that there is difference between conditions of the sale contract (shurüt al-bay') and conditions within the sale contract (shurüt fi albay ). The former refers to something without which the sale cannot be valid; they are stipulated by the Lawgiver, not by man. Some examples of them are: the condition of the consent of contracting parties, the condition for the subject matters to be known, being deliverable and possessed by the seller, etc. The latter refers to something which is initiated and stipulated by man. Some examples of them are: the condition of collateral, guarantee by any contracting party, stipulation to exclude any known and common benefit of the subject matter (like the use of the car for a specific period), a stipulation to ask any defined task from the seller such as chopping the wood, and so forth. In short, shart is such an attribute upon which the ruling depends for its existence, but in its absence the ruling also would be absent.

\section{CLASSIFICATIONS OF CONDITIONS}

With regard to the application, conditions are classified into two. First, the condition which affects the cause i.e. complements the cause and gives it its full effect. Passing one year, for example, complements the nișāb, which is the cause of zakāh to be obligatory. So, nișāb will not be effective as a cause for the obligation of zakāh unless one year has passed. Second, the condition which affects the rule; it means the rule of something exists when the condition is present. For instance, the death of someone, and they having heir, are two conditions for inheritance. So, these two conditions complement the rule which

11 'Abd al-Qādir Ibn Badrān, al-Madkhal ilā Madhhab al-Imām Aḥmad Ibn Hanbal, vol. 1 (Beirūt: Mu'assasat al-Risālah, 1991), 158. 
is bequest, and hence the consequence of inheritance, i.e. giving each heir his/ her right in legacy, cannot be applied without death and heirs. ${ }^{12}$

Concerning the source, conditions are classified into two. First, a legal condition (shart shar' $\vec{l}$ ), which is a condition given by the Lawgiver, such as the conditions prescribed in the shart' $a h$ with respect to worship, transactions, penalties, and the like. Islam, puberty and sanity for example, are the conditions for the prayer to be mandatory, for performing Hajj, for consent for transferring property in a sale contract, etc. So, these are given by the Lawgiver, as a condition for the validity of worship, transaction penalties, and so on.

The second type of condition is the improvised condition (shart al-ja ' $\imath \vec{\imath})$ : it refers to the conditions laid down by a mature and sane individual who is party to the contract. These are usually stipulated by people in their contracts and dealings. This type is further subdivided into two kinds: firstly, the condition on which the contract is grounded. This means the contracting party concludes the contract subject on the actualization of the condition stipulated. This is seen in the arrangement of kafälah (guarantee) for example, which is subject to the inability of the debtor to settle the debt. This is called al-shart al-mu 'allaq. Secondly, the condition associated with the contract: it may happen that the contract concludes without being subject to any condition yet it is associated with an extra condition stipulated by any of the contracting parties to attain the benefits with the agreement of the other party. For example, the seller of the house stipulates that he will stay in the house one month and only after will it be under the official ownership of the buyer. This is called al-shart almuqtaran bi al- 'aqd. ${ }^{13}$

\section{CONDITION IN THE PROMINENT SCHOOLS OF ISLAMIC LAW}

\section{Hanafĩ School}

The principle of the Hanafi School is that if the condition is something which is required by the contract, such as a condition of settlement and delivery, it is valid. In fact, this is not a real condition as it denotes the same as what a typical contract would expect. Thus, this sort of condition does not add anything except emphasis. Nevertheless, if the condition is not required by the contract, but is rather a matter of convenience, it is permitted based on

12 Hāshim Fāris 'Abdūn, al-Shart wa Athāruhū fì 'Aqd al-Bay 'wa al-Nikāh, 3; 'Abd al-Wahhāb Khallāf, Ușūl al-Fiqh, 140; Zaydān, al-Wajiz fì Ușūl al-Fiqh, 140.

13 Hāshim Fāris 'Abdūn, al-Sharț wa Athāruhū fì 'Aqd al-Bay ' wa al-Nikāḥ, 3; 'Abd al-Wahhāb Khallāf, Ușūl al-Fiqh, 140; Zaydān, al-Wajīz fì Ușūl al-Fiqh, 140. 
juristic preference (istihsān), although general reasoning invalidates this, such as the condition of mortgages and guarantees, etc. In addition, if the condition is neither required by the contract, nor convenient for the contract, but is a customary practice, such a condition is valid as far as juristic reasoning (qiyās) is concerned. But this school validates it based on juristic preference (istihssān) because what is established by custom is predominant on reasoning, and reasoning will be overlooked due to custom and peoples' practice as in the case of a manufacturing contract. However, if the condition is not required by the contract, nor convenient for the contract, nor grounded in custom, such a condition is invalid. So if there is any benefit for any contracting parties, the condition is invalid and accordingly this makes the contract void. However, if there is no benefit, the contract is valid while the condition is invalid. ${ }^{14}$

\section{Mālikī School}

In the Malikī School conditions are divided into three categories: conditions that are void and invalidates the contract accordingly, conditions where both the condition and the contract are valid, and conditions which are invalid, but the contract is valid. If the buyer stipulates for him a little benefit that does not prevent to deal in the sold object, such as to sell the house and to stipulate the dwelling thereof for a short period - one month for instance - it is valid. However, if he stipulates something that prevents the other party from a general or specific dealing in the subject matter, such as to sell something with the condition that the buyer cannot sell it, such a stipulation will be invalid as it is considered two contracts in a single arrangement, which is forbidden. ${ }^{15}$

\section{Shāfíīi School}

According to the Shāfi' $\overline{1}$ School, if a condition is required by the contract, such as delivery and possession, or returning the subject matter due to fault, or allowing the purchaser rights to utilize the object in whatever way he wants, etc., scholars unanimously agree that these do not invalidate the contract, rather they affirm and emphasize the requirements of the contract. Additionally, if a

14 'Alā al-Dīn Abū Bakr al-Kāsān̄i, Badā'i' al-Sanā' $i$ ' fì Tartīb al-Sharā'i'، vol. 7 (Cairo: Dār al-Hadīth, 2005), 12; al-Fatāwā al-Hindiyyah fì Madhhab alHanafiyyah, vol. 3 (Beirūt: Dār al-Fikr, 2010), 134.

15 Ibn Rushd, Bidāyat al-Mujtahid, vol. 2 (Beirūt: Dār al-Kutub al-'Ilmiyyah, 2003), 253; Muḥammad Ibn 'Abd Allāh al-Kharshī, Sharh al-Kharshī 'alā Mukhtaṣar Khalīl, vol. 5 (Beirūt: Dār al-Kutub al-'Ilmiyyah, 1997), 402. 
condition is not required by the general sense of the contract, yet there is benefit for the contracting party, like the condition of three days' option, deferment, mortgage, guarantee, etc. such a condition does not invalidate the contract rather it is valid and effective. However, if the condition contradicts the requirements of the sale contract, such as to sell something that the purchaser is not allowed to sell, or utilize, or lend, or lease, etc. the it is t valid. In all these cases and the like the sale will be invalid as it is contrary to the requirement of the contract, and there is no difference whether it is stipulated with one or more conditions. ${ }^{16}$

\section{4. Ḥanbalī School}

In the Hanbali School conditions are initially classified into two categories: valid and invalid. Among the valid conditions are thse which are consistent with the requirements and normal sequence of the contract such as the condition of delivery, option by stipulation, instant possession, and so on. This sort of condition does not have any effect on the ruling and hence its existence and effect are alike. The second type is the condition that is pertinent to the interests of the contracting parties like deferment, option, mortgage, guarantee, etc. The third type of valid conditions is that which stipulates the benefit specified in the subject matter, like the riding of an animal, the dwelling in the house, etc.

On the other hand, among the invalid conditions is that which stipulates two contracts in a single arrangement, such as selling something provided that he should sell him another thing, or he should buy from him, or rent him something, or lend him, etc. This sort of condition is invalid and accordingly invalidates the contract. Another type of invalid condition is that which stipulates something that is contrary to the requirements of the contract, such as selling something provided that the buyer cannot sell, or lease, or donate, or otherwise. This condition is invalid, but the contract remains valid. The third type of invalid condition is that which makes the contract contingent upon something outside of it. In this case both condition and contract are invalid. ${ }^{17}$

16 Yahyyā Ibn Sharaf al-Dīn al-Nawawī, Rawụat al-Ṭālibīn, vol. 3 (Cairo: al-Maktabat al-Tawfiqiyyah, 2000), 82; Abū Isḥāq al-Shīrāzī, al-Muhadhdhab fì Fiqh al-Imām al-Shāfi 'ì, vol. 2 (Beirūt: Dār al-Kutub al-'Ilmiyyah, 1995), 22.

17 Shams al-Dīn 'Abd al-Raḥmān Ibn Qudāmah, al-Sharh al-Kabīr with al-Mughnī vol. 5 (Cairo: Dār al-Ḥadīth, 2004), 277-289; al-Buhūtī, Kashshāf al-Qinā', vol. $3,217$. 


\section{DISCUSSION AND ANALYSIS}

\section{Valid Condition:}

\section{The Parameters for Valid Conditions:}

According to the Hanafi School, if any attribute is stipulated in the subject matter upon conclusion of the contract - or anything which is required by the contract, consistent with that, common in the customary practice, or permitted in the Shariah - is considered a valid condition. In the Maliki School the condition which is neither required nor contrary to the contract is considered valid. The Shāfi' $\overline{1}$ School opines that if it is required by the contract, or implements the interest of any of the contracting parties, it is considered a valid condition. According to the Hanbali School, something that is required by the contract or affirms its requirement, is lawful in the Shariah, or benefits the contracting parties, is considered a valid condition. ${ }^{18}$

\section{Valid Condition in Various Schools of Islamic Law:}

\section{Essential Condition:}

According to the Hanafi School, the conditions that are required by a contract, such as the condition of the seller to pay the price, the condition of the buyer to possess the merchandise, the condition of the tenant to utilize the rented asset, etc. are not considered conditions in substance. These are not the conditions in a real sense because they are commonsensical and are emphasized in the contract itself. Moreover, the contract with these conditions is the same as an unconditional and general contract. ${ }^{19}$ Thus, article (186) of the Majallah ${ }^{20}$ states, "If a sale arrangement is concluded with an essential condition attached, both sale and condition are valid." For example, if someone sells

18 Ministry of Awqāf and Islamic Affairs, al-Mawsū'ah al-Fiqhiyyah, vol. 26 (Kuwait, 1992), 11.

19 Al-Kāsānī, Badā'i ' al-Sanā̄'i', vol. 7, 13; al-Fatāwāa al-Hindiyyah, vol. 3, 134.

20 This is Majallat al-Ahkām al-'Adliyyah known as 'The Mejelle' which was composed between $1869 \mathrm{CE}$ and $1876 \mathrm{CE}$ as part of the legislative process of the tanzīmāt initiated by the Ottoman Caliphate. It represents an attempt to codify that part of the Hanafí fiqh which deals with civil transactions ( $m u$ 'ámalät). The Majallah contains 1851 articles that encompass legal (shar $\vec{\imath}$ ) provisions for the various civil transactions, such as sale, rent, guarantee, agency, etc. with compact pattern that organized the fiqhi issues which were dispersed and scattered. 
with the condition that he retains the subject matter until the price is received, such a condition does not prejudice the sale, but only declares what is required by the contract. ${ }^{21}$

In the Mālikī School, there are several valid conditions, such as the conditions that are required by the contract and do not encompass rib $\bar{a}$, gharar, etc. Some examples of them are: to sell with the condition of delivery of the merchandise, returning the subject matter due to defect, giving back the consideration upon revocation of the contract and so forth. ${ }^{22}$ According to the Shafi'i School, the conditions that are required by the sale contract, such as the possession and utilization of the subject matters, returning the subject matter due to defect, etc. neither benefit nor harm the contract, and accordingly both the conditions and the sale are valid. ${ }^{23}$ According to the Hanbali School, these conditions that are the requirement and normal sequence of a contract, such as the condition of delivery of the merchandise, and the condition of the settlement of the price, etc. do not have any effect on the ruling and hence their existence or absence are alike. ${ }^{24}$ Thus, article (186) of the Majallah conforms to the Hanafi School as well as other schools of Islamic law.

\section{A Strengthening Condition:}

According to the Hanafi School, adding a condition to a contract was not required as it is only a matter of convenience. The Hanafi School permitted this condition based on the juristic preference (istiḩsān) while analogy (qiyās) considers it void and invalid. An example of this type of condition is the condition of mortgage and guarantee to secure the price. Al-Kāsānī says that although this condition apparently contradicts the requirement of the contract, it conforms to the substance of the contract. Thus, a pledge for the price is legalized to secure the price. Likewise, in the case of the guarantee, the seller

21 Al-Majallah (Beirūt: al-Mațba'at al-Adabiyyah, 1302AH), 41.

22 Ibn Rushd, Bidāyat al-Mujtahid, vol. 2, 253; Hāshiyat al-Kharshī, vol. 5, 402.

23 Al-Nawawī, Rawụtat al-Ṭālibīn, vol. 3, 82; Shihāb al-Dīn al-Qalīyūbī wa 'Amīrah, Hāshiyat al-Qalīyūbì wa 'Amīrah, vol. 2 (Beirūt: Dār al-Kutub al-'Ilmiyyah, 2003), 286; Shams al-Dīn Muhammad Ibn Aḥmad al-Ramlī, Nihāyat al-Muḥtāj ilā Sharḥ al-Minhājj, vol. 3 (Beirūt: Dār al-Kutub al-'Ilmiyyah, 1993), 459; alShīrāzī, al-Muhadhdhab, vol. 2, 22.

24 Ibn Qudāmah, al-Sharh al-Kabīr with al-Mughnī, vol. 5, 277; 'Alā al-Dīn alMardāwī, al-Inșāf fì Ma 'rifat al-Rājịh min al-Khilāf 'alā Madhhab al-Imām Ahmad Ibn Hanbal, vol. 4 (Beirūt: Dār al-Kutub al-'Ilmiyyah, 1997), 327; alBahūtī, Kashshäf al-Qinā', vol. 3, 217. 
keeps the right to secure the contract with collateral, which confirms and establishes the requirements of the contract. ${ }^{25}$ Article (187) of the Majallah states:

"A sale with a condition in support of a requirement of the contract is valid and the condition is effective."

For example, to sell a thing with a condition that the buyer should keep something to the seller as a pledge, or manage a guarantor for him; such a sale is valid and the condition is effective, even if the buyer does not observe the condition. Moreover, the seller can annul the contract, because the condition is in support of the payment of the price, which is a requisite part of the contract. ${ }^{26}$

The Mālikī School opines that the condition which does not contain any prohibited element like riba $\bar{a}$, gharar, etc. but affirms the requirements of the contract is valid along with the sale arrangement. ${ }^{27}$ According to the Shāfi ' $\overline{1}$ School, a condition is not required by the general sense of the contract, yet there is benefit for the contracting party, like the condition of three days' option, deferment, mortgage, guarantee - and in case of the slave - the condition of being the writer, tailor and so forth. These do not invalidate the contract, but are rather valid and will be effective accordingly. ${ }^{28}$ The Hanbali School opines that the conditions that are pertinent to the interest of the contracting parties, like the deferment, option, mortgage, guarantee, etc. are valid. Also, to stipulate some attributes in sold objects such as writing, handicraft, etc. are valid and permissible conditions and they must be fulfilled accordingly. ${ }^{29}$ So, article (187) of the Majallah conforms to the Hanafi School as well as other Schools of Islamic law.

\section{A Customarily Known Condition:}

A sale arrangement subject to a condition sanctioned by the custom that is established and recognized in a particular locality is valid; and both sale and condition are valid in this regard. The Hanafí i School identifies this as the condition that is neither required by the contract, nor is it convenient for the contract, but people used to practice this and it has become customary among

\footnotetext{
25 Al-Kāsānī, Badā' 'i 'al-Șanā'i ', vol. 7, 14; al-Fatāwā al-Hindiyyah, vol. 3, 134.

26 Al-Majallah, 41.

27 Ibn Rushd, Bidāyat al-Mujtahid, vol. 2, 253; Hāshiyat al-Kharshī, vol. 5, 402.

28 Al-Nawawī, Rawḍat al-Ṭālibīn, vol. 3, 82; Hāshiyat al-Qalīyūbī wa 'Amīrah, vol. 2, 287; al-Ramlī, Nihāyat al-Muhtāj, vol. 3, 460; al-Shīrāzī, al-Muhadhdhab, vol. 2,22 .

29 Ibn Qudāmah, al-Sharh al-Kabīr, vol. 5, 277; al-Mardāwī, al-Inșāf, vol. 4, 327; al-Bahūtī, Kashshāf al-Qinā', vol. 3, 218.
} 
them. This condition is invalid as far as juristic reasoning (qiyās) is concerned. Yet they have validated it relying on juristic preference (istihsān) since what is established by custom is predominant to reasoning, and reasoning will be overlooked due to custom and peoples' practice as in the case of a manufacturing contract (istișnā ). ${ }^{30}$ Thus, article (188) of the Majallah states:

"A sale with a condition, which is common and known in the custom of the city, is valid and the condition is effective." 31

For example, if someone buys a lock with the condition that the seller fastens it on the door, or buys the garment provided that he patches it, the sale is valid and the seller has to comply with these conditions.

The Mālikin̄ School maintains that if the seller stipulates some benefits for himself, which is little and customarily recognized, and which does not prevent anyone from dealing in the subject matter, then such a condition is valid. For example, if the house is sold with the condition of dwelling in it for one month, then such a sale is valid. ${ }^{32}$ Imām Mālik says that stipulating residence for one month up to one year is acceptable, but not for more than that. ${ }^{33}$ However, the Shāfi'i School opines that if the seller stipulates some benefits for him in the subject matter which are contrary to the requirement of the sale, then such a condition is invalid. For example, if one sells a house with the condition that he will stay there one month, then both the condition and sale are invalid. ${ }^{34}$ According to the Hanbali School, if the seller stipulates some benefits that are rendered to him, which are known and common in the customary practice, then such conditions are valid. For example, selling the house with the condition of one month residing thereof, or selling the animal with the condition of a ride to a known place, etc. are valid. ${ }^{35}$ So, regarding this issue the respective article of the Majallah conforms to all the prominent schools of Islamic law.

\footnotetext{
30 Al-Kāsān̄̄, Badā' ' ${ }^{\prime}$ al-Șanā’ $i$ ', vol. 7, 15.

31 Al-Majallah, 42.

32 Ibn Rushd, Bidāyat al-Mujtahid, vol. 2, 254.

33 Mālik Ibn Anas, al-Mudawwanah al-Kubrā, vol. 4 (Cairo: Dār al-Hadīth, 2005), 225.

34 Al-Nawawī, Rawḍt al-Ṭālibìn, vol. 3, 82; Hāshiyat al-Qalīyūbì wa 'Amīrah, vol. 2, 287; al-Ramlī, Nihāyat al-Muhtāj, vol. 3, 460; al-Shīrāzī, al-Muhadhdhab, vol. $2,23$.

35 Al-Mardāwī, al-Inșāf, vol. 4, 331; Ibn Qudāmah, al-Sharh al-Kabīr, vol. 5, 281; al-Bahūtī, Kashshäf al-Qinā', vol. 3, 219.
} 


\section{Invalid Condition}

The Parameter for Invalid Conditions: Muslim jurists opine that the invalid condition is such which leads to excessive ambiguity (gharar), or stipulates a prohibited item, or stipulates something that is not required by the contract while it benefits anyone of the contracting parties or the subject matter, or stipulates something that is neither consistent with the requirements of the contract nor common in the custom, etc. ${ }^{36}$

\section{Invalid Condition in Various Schools of Islamic Law:}

The Hanafi School opines that the condition which is neither required by the contract, nor is convenient for the contract, nor is grounded on the custom and usage of the people, is invalid. In this case the condition renders a benefit to any of the contracting parties then the condition is invalid and accordingly it invalidates the sale as well. This is because the benefit which is stipulated in the contract for one of the contracting parties does not take into consideration the interest $(r i b \bar{a})$ in substance. However, if the condition does not render any benefit to any party then the condition is invalid, but the sale remains valid. Nevertheless, another stand of this school opines that in this case, both the condition and the sale are invalid. ${ }^{37}$ Thus, article (189) of the Majallah states:

"In the case of sale subject to a condition which is not to the benefit of either party, the sale is valid but the condition is voidable."

For example, selling an animal subject to a condition that it shall not be sold to a third party or that it shall be put out to graze, in such a case the sale is valid, but the condition is not effective. ${ }^{38}$

The Mālikī School opines that invalid condition are such which are contrary to the normal sequence of the contract and which prevents the buyer from dealing in the subject matter, such as selling something provided that the buyer cannot sell it to a third party, or cannot donate it to anybody and so forth. This condition is invalid and would be considered to be two contracts in a single arrangement. ${ }^{39}$ According to the Shäfi' $\overline{1}$ School, the invalid condition is something that is contrary to the requirement of the contract, such as a stipulation of not having possession and delivery, and so forth. This condition

\footnotetext{
36 Al-Mawsū'ah al-Fiqhiyyah, vol. 26, 13.

37 Al-Kāsānī, Badā' 'i ' al-Sanā' 'i ‘, vol. 7, 12; al-Fatāwā al-Hindiyyah, vol. 3, 134.

38 Al-Majallah, 42.

39 Ibn Rushd, Bidāyat al-Mujtahid, vol. 2, 254; Hāshiyat al-Kharshī, vol. 5, 401.
} 
is invalid and also invalidates the contract. ${ }^{40}$ However, if there is a condition that renders benefit to none of the contracting parties, then such a condition is invalid, but the contract is valid..$^{41}$ According to the Hanbali School, among the invalid conditions is to stipulate on each other another contract, such as a loan, giving credit, sale, lease, etc. This sort of condition invalidates the sale arrangement. Also, another invalid condition is to stipulate something that is contrary to the requirement of the sale, such as selling something with the condition of not selling to a third party, not to donate, or selling a slave with the condition of not emancipating, etc. This type of condition is void, but does not invalidate the sale contract. ${ }^{42}$

\section{Evidences with Discussion:}

As mentioned above, all the schools agree that if a condition is required by the contract, or is not required but renders benefit to the contract, or is common and known in customary practice, then such a condition is valid and effective. The validity of this sort of condition is grounded on the hadith whereby the Prophet (PBUH) stated:

"Muslims would be judged pursuant to the conditions they stipulate, except the condition that prohibits the legal things or allows the illegal things." 43

However, if a condition is neither required by the contract, nor renders any benefit to the contract, nor is common in the custom, then such a condition is invalid and invalidates the contract as well. Nevertheless, if there is a condition that stipulates the right for the seller to enjoy some benefits from the sold object, then the scholars have differed in two ways. The Hanafi and Shāfi' $\overline{1}$ Schools opine that such a condition is invalid. ${ }^{44}$ These two schools argue using the hadith which says: "The Prophet forbade the sale and the

40 Hāshiyat al-Qalīyūbī wa 'Amīrah, vol. 2, 286; al-Shīrāzī, al-Muhadhdhab, vol. 2, 23.

41 Al-Ramlī, Nihāyat al-Muhtāj, vol. 3, 459.

42 Al-Mardāwī, al-Inșāf, vol. 4, 336; Ibn Qudāmah, al-Sharh al-Kabīr, vol. 5, 284; al-Bahūtī, Kashshäf al-Qinā', vol. 3, 222.

43 Muhammad Ibn Ismā '̄il al-Bukhārī, Șaḥịh al-Bukhārī, Bāb Ajr al-Samsarah. This is one of the ta 'liqqat (without mentioning the chain of narration) of Imam alBukhārī, vol. 2, hadīth no: 2274 (Beirūt: Dār al-Kutub al- 'Ilmiyyah, 2002), 60; Sulaymān Ibn al-Ash'ath al-Sajistānī, Sunan Ab̄i Dāwūd, Bāb fì al-Ṣulh, hadìth no: 3594 (Beirūt: Dār Ibn Ḥazm, 1997), 4:16.

44 Al-Kāsān̄̄, Badā'i ‘ al-Ṣanā'i', vol. 7, 12; Hāshiyat al-Qalīyūbì wa 'Amīrah, vol. 2, 286; al-Shīrāzī, al-Muhadhdhab, vol. 2, 23. 
condition." ${ }^{45}$ Also, such a condition is contrary to the requirement of the sale as the delivery of subject matter will be delayed until the seller finished his utilization of the subject matter. The Mālikī School opines that if the benefit is little and customarily known, it will then be valid. ${ }^{46}$ Imām Mālik says that stipulating to ride an animal for one or two days or the like is accepted, but for more than that, like one month, is not accepted. ${ }^{47}$ However, according to the Hanbalī School, such a condition is valid. ${ }^{48}$ The Mālikī and Hanbali Schools argue with the hadìth of Jābir whereby the Prophet (pbuh) purchased his camel and stipulated that he be allowed to ride on it to Madinah. ${ }^{49}$ The authors prefer to opine that if the condition of enjoying such benefit is little and customarily known, then such a condition is valid, as the Māliki School advocates.

\section{CONTEMPORARY APPLICATIONS}

As discussed above, all the prominent schools of Islamic law have agreed that if the condition stipulated in the sale arrangement is an essential part of the contract - in accordance with the requirements and normal sequence of the contract and renders benefit to any of the contracting parties provided that it is customarily known and recognized - then such a condition is valid and effective. However, if a condition contradicts the requirements of the contract, or there is no benefit for any of the contracting parties, then such a condition is invalid. Nowadays, there is hardly any transaction without terms and conditions. So, these transactions should be judged according to the status of the terms and conditions stipulated. If these terms are essential and conform to the normal sequence of the contract, or render benefit for the contracting parties which is known and recognized in customary practice, then both transactions and conditions are valid. If these terms and conditions contradict the normal flow of the contract, and do not render any benefit but rather harm the contracting parties, the transaction would then be invalid unless such terms and conditions are removed. Nevertheless, some contemporary examples and applications of the sale subject to a condition are mentioned below:

$\overline{45}$ Nūr al-Dīn 'Alī Ibn Abī Bakr Al-Haythamī, Majma 'al-Zawā'id wa Manba' alFawā'id, Bāb mā jā' a fì al-Șafaqatayn fì al-Safaqah, vol. 4 (Beirūt: Dār al-Kutub al-'Ilmiyyah, 2001), no. hadīth 6386, 104.

46 Ibn Rushd, Bidāyat al-Mujtahid, vol. 2, 254.

47 Mālik, al-Mudawwanah al-Kubrā, vol. 4, 225.

48 Ibn Qudāmah, al-Sharh al-Kabìr, vol. 5, 279.

49 Al-Bukhārī, Șahīh al-Bukhārī, Kitāb al-Syurūṭ, bāb idhā Ishtarața al-Bā' 'i ‘ u Dhahr al-Dābbah, no. hadīth 2718, vol. 2, 193; Abū al-Ḥusayn Muslim ibn al-Hajjāj AlNīsābūrī, Șaḥ̄h Muslim kitāb al-Musāqāt, bāb Bay 'al-Ba 'ìr wa Istithnā'rukubihi, no. hadīth 715 (Beirūt: Dār al-Kutub al-'Ilmiyyah, 2003), vol. 6, part, 11: 25. 
a) Currently no financing facility is given by banks or financial institutions unless the client has something that could be kept as collateral or mortgage to the banks or financial institutions. The condition of providing collateral or mortgage is consistent with the contract. It strengthens the requirements of the contract and affirms the commitment of the client to settle the debt. So, such a condition is valid.

b) Nowadays automobiles are offered and sold with the condition that if the price is settled in cash it will be cheaper, and if it is on credit, the more expensive. This sort of sale with the condition of paying double or more in case of being on credit is permissible, provided that both prices are mentioned independently and both parties are aware of these two prices: the cash price and the deferment price. So, before the conclusion of the contract both parties must agree on one of the two prices; otherwise the sale is not permissible since there is the risk of not knowing the price and the payment method. ${ }^{50}$ This kind of sale with such a condition has become common and known in the present time and this is valid.

c) If a person purchases a house and stipulates to the seller that he must rent a portion of the house with the amount specified; or on the other hand, the seller stipulates on the buyer that he shall not sell this house to anybody expect the first owner; then this sort of arrangement is invalid because it is in fact two sales in a single arrangement, which is forbidden in the hadith. ${ }^{51}$

d) Posting a notice "the goods can neither be returned nor changed" in the shop has nowadays become a common practice. However, in some cases there is a chance to change within a specified number of days. The sale with the condition of having no chance to return or to change is not permissible, and this condition is invalid as well. This condition is contrary to the requirement of the contract as the buyer may not be able to fulfill his needs, if the goods have a defect and he does not have a chance to change or to return. Moreover, this might cause harm and hardship to the clients. Also, according to the Islamic law of contracts, if any defect is found in the goods the purchaser shall be compensated accordingly. So, the condition of

\footnotetext{
50 Aḥmad Ibn 'Abd al-Razzāq al-Dawīsh, Fatāwā al-Lajnah al-Dā'imah li al-Buhūth al- 'Ilmiyyah wa al-Iftā', vol. 13 (Cairo: Ūlī al-Nuhā, 2003), 192.

51 Aḥmad Ibn 'Abd al-Razzāq al-Dawīsh, Fatāwā al-Lajnah al-Dā' imah li al-Buhūth al-'Ilmiyyah wa al-Iftā', 194.
} 
having no opportunity to alter or to change is invalid and it invalidates the sale contract as well. ${ }^{52}$ Allah SWT says:

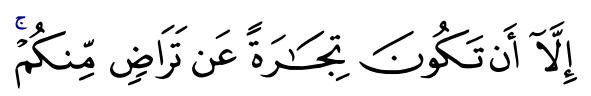

"But let there be amongst you traffic and trade by mutual goodwill."

(Surah al-Nisā', 4: 29)

Having knowledge of the defect in the subject matter is contrary to the consent stipulated in contracts. So, the contract that contains any defect would be a trade without consent. Also, the verse indicates that the contracting party is not bound to accept the subject matter that is defective; but rather he can reject and return it, irrespective of the way of returning and fixing that defect in equality of exchange. ${ }^{53}$ In addition, it is reported on the authority of ' $\bar{A}$ 'ishah that someone bought a slave and utilized him and then found fault in the slave and returned him on account of the defect. The seller said: "Where is the income of my slave?" Then the Prophet says: "al-kharāj bi al-damān", i.e. benefit goes with liability. ${ }^{54}$ Thus, as per Islamic law, if there is any fault found in the merchandise the buyer shall be allowed either to return it or be compensated accordingly.

e) If someone says: "buy the goods from me, and if you make loss I will compensate you", such a condition is invalid, but the sale is valid. This is because once the contract is concluded and payment is settled the goods sold are transferred to the possession of the buyer and he has absolute rights over them. In this case, whatever profit or loss he makes would be for him, while the seller shall not have any interest thereof. ${ }^{55}$ So, such a condition of giving compensation is meaningless, yet the sale is permissible and effective.

f) Sometimes the tradesman stipulates that the purchaser may return the goods, but will not be refunded the price. Nevertheless, the purchaser may

52 Aḥmad Ibn 'Abd al-Razzāq al-Dawīsh, Fatāwā al-Lajnah al-Dā'imah li al-Buhūth al-'Ilmiyyah wa al-Iftà', 197.

53 Ibn Rushd, Bidāyat al-Mujtahid, vol. 2, 273; al-Kāsānī, Badā 'i ' al-Ṣanā 'í, vol. 7, 266.

54 Al-Sajistānī, Sunan Abū Dāwūd, Bāb fì man ishtara 'abdan fasta 'malahu thumma wajada bihi 'ayba, hadīth no. 3508, vol. 3, 500; Abū 'Īsā Muhammad Ibn 'Īsā alTirmidhī, Sunan al-Tirmidhī, Bāb Mā jā'a fìman yashtari al- 'abd wa yastaghilluhu thumma yajidu bihi 'ayban, hadīth no: 1285, vol. 2 (Beirūt: Dār al-Kutub al'Ilmiyyah, 2000), 304.

55 Al-Dawīsh, Fatāwā al-Lajnah al-Dā'imah, vol. 13, 198. 
buy other things available to the tradesman what he wants corresponding to the price of the goods returned. If the purchaser does not find anything with the tradesman that satisfies his needs, the tradesman holds the price until the purchaser utilizes that to buy anything from his shop which satisfies his needs. As per the provision of Islamic law, it is permissible for the contracting parties to stipulate an option to accept or reject the sale for a specific period of time. Pursuant to this option by stipulation (khiyār al-shart), the purchaser may return the merchandise within the duration specified and get back the price which he settled to the seller. Thus, it is not permissible to stipulate that the buyer will not be refunded the price and he has to purchase another item from the seller instead. This is an invalid condition and cannot come into effect as far as the Shariah is concerned. ${ }^{56}$

g) If someone sells his house at less than the market price, with the condition that he will enjoy a privilege to rent the house with a token amount of monthly rental till he dies, and thereafter the buyer will have the right to deal in the house in whatever way he wants, this would be an invalid form of sale because it encompasses two contracts in one arrangement: a sale contract and then a lease contract. Additionally, this form of sale contains a condition that includes ambiguity (gharar) and ignorance (jahālah), and that is the condition of retaining the house in the possession of the seller in return for a token rental amount till an unknown period as nobody knows when his life will come to an end except Allah SWT. Thus, such a condition is invalid and invalidates the sale as well. ${ }^{57}$

h) Currently Islamic banks and Islamic financial institutions practice costplus-profit (murābahah) sale to offer murābahah financing for their clients. Actually this muräbahah arrangement includes several clauses and conditions, such as general conditions of dealings, sale and purchase of goods, promise to purchase from the client, securities against murābahah price, guaranteeing the murābahah, penalty of default, and so forth. From the perspective of the Shariah, no issue would arise to place these conditions into the arrangement because all these together make one indivisible contract. These are valid conditions because they affirm the requisites of the contract; albeit some of them in particular have been subjected to debate among the contemporary Shariah scholars, like the issue of promise, penalty, rebate on early payment, and so on. ${ }^{58}$

56 Al-Dawīsh, Fatāwā al-Lajnah al-Dā'imah, vol. 13, 199.

57 Aḥmad Ibn Ḥamd al-Khalīìi, Fatāwāa al-Mu 'āmalāt, vol. 3 (Oman: al-Ajyāl li alTaswīq, 2003), 102.

58 'Abd al-Majīd Maḥmūd al-'Ibādī, 'al-Taṭbīqāt al-Mu'āṣarah li al-Shurūṭ alMuqtaranah bi al-'Uqūd al-Māliyyah,' (Ph.D Thesis, Jordan University, 2004), 98. 
Furthermore, the condition of option by stipulation (khiyār al-shart ) also could be applied to the contemporary murābahah financing. A person asked Imam Muhammad ibn al-Hasan al-Shaybānī: "What do you think about the case whereby someone requests a person to buy a house for him with one thousand dirham and then informs that he will purchase it with one thousand and one hundred dirham from him. So, the man who is requested wants to buy the house, but he fears that if he buys the person who has requested may not purchase it from him, whereby the house will remain in his custody. So what would be the way to get rid of this situation?" Imam Muhammad replied: "The man who is requested will buy the house, subject to having the option for him till three days. Then he will possess the house and the person who has requested will come and tell him that, 'I have taken the house from you with one thousand and one hundred dirham, while the other person says that I have accepted, and here is the house for you.' Such a request would be binding upon the person who makes it, and the arrangement would be the response from the person who accepts the request." 59 So, stipulating the option (khiyār al-shart) for three days could be a way to minimize the risk of holding the house in the buyer's custody. If in the end customer does not buy the house then the buyer may return it to the supplier during the option period stipulated.

Nevertheless, this scenario could be applied in contemporary murābahah financing, which is practiced widely in Islamic banks and Islamic financial institutions all over the world. The practical steps could be as follows: First, the financing institution receives a request from the customer to buy a commodity for him. Then both the institution and the customer sign an agreement whereby the institution promises to sell and the customer promises to buy the commodity on an agreed profit ratio added to the cost. Second, the institution will buy the desired commodity that the customer promises to buy, while stipulating the right for him to revoke within the period specified which shall suffice to obtain the contentment of the customer to purchase the commodity. Third, the institution asks the customer to execute his promise to purchase. Once the customer buys the commodity and the institution agrees on that, the option would be terminated. So, the option would expire merely by the endorsement of the institution on the sale of the commodity. ${ }^{60}$

\footnotetext{
59 Muhammad Ibn al-Ḥasan al-Shaybān̄̄, al-Makhārij fì al-Hiyal (Cairo: Maktabat al-Thaqāfah al-Dīniyyah, 1999), 40.

60 'Umar Sulaymān al-Ashqar, Khiyār al-Shartfĭ al-Buyū ' wa Taṭ̆̄̄quhu fì Mu 'āmalāt al-Mașārif al-Islāmiyyah (Jordan: Dār al-Nafâ’' is, 1993), 65.
} 


\section{CONCLUSION}

Basically, the ruling of the sale with a condition depends on the status of the condition. If the condition conforms to the requirements of the contract, affirms it, is customarily known and does not contain any prohibited element, then such a condition is valid and the contract is valid as well. However, if the condition contradicts the requirements of the contract, contains prohibited elements, and does not render any benefit to the parties concerned, then such a condition is invalid and accordingly invalidates the sale. Currently there is hardly any contract that is free from conditions. Almost all transactions are attached with respective terms and conditions. So, the judgment on these transactions should be subject to the status of the condition. If the condition is consistent with the requirements of the contract and the Shariah, it should be valid and effective accordingly. Any condition having contradiction with the requisites of the contract and Shariah is invalid and accordingly it invalidates the transaction as well.

\section{REFERENCES}

Al-Ashqar, 'Umar Sulaymān, Khiyār al-Shart fì al-Buyū' wa Taṭīquhu fì Mu 'āmalāt al-Mașārif al-Islāmiyyah (Jordan: Dār al-Nafā'is, 1993).

Al-Bahūtī, Manșūr ibn Yūnus, Kashshāf al-Qinā' 'an Matan al-Iqnā' (Beirūt: Dār al-Kutub al-'Ilmiyyah, 1997).

Al-Bukhārī, Muḥammad Ibn Ismā'īl, Șaḥ̄ḥ al-Bukhārī (Beirūt: Dār al-Kutub al-'Ilmiyyah, 2002).

Al-Dawīsh, Aḥmad ibn 'Abd al-Razzāq, Fatāwā al-Lajnah al-Dā'imah li alBuhūth al-'Ilmiyyah wa al-Iftā' (Cairo: Ūlī al-Nuhā, 2003).

Al-Fatāwā al-Hindiyyah fi Madhhab al-Hanafiyyah (Beirūt: Dār al-Fikr, 2010).

Al-Ḥanafī, 'Ubayd Allāh Ibn Mas'ūd, al-Taw dīh li Matn al-Tanqīh fì Uṣūl alFiqh (Beirūt: Dār al-Kutub al-'Ilmiyyah, n.d.).

Al-Hanbalī, Abū al-Khațāāb Maḥfūẓ, al-Tamhīd fì Ușūl al-Fiqh (Beirūt: Mu'assasat al-Rayyān, 2000).

Haqqi, Abdurrahman Raden Aji, The Philosophy of Islamic Law of Transactions (Kuala Lumpur: CERT Publications, 2009).

Al-Haythamī, Nūr al-Dīn 'Alī ibn Abī Bakr, Majma' al-Zawā'id wa Manba' al-Fawā'id (Beirut: Dār al-Kutub al-'Ilmiyyah, 2001). 
Al-'Ibād̄̄, 'Abd al-Majīd Maḥmūd, 'al-Taṭbīqāt al-Mu'āṣarah li al-Shurūṭ alMuqtaranah bi al-'Uqūd al-Māliyyah,' (Ph.D Thesis, Jordan University, 2004).

Ibn Anas, Mālik, al-Mudawwanah al-Kubrā (Cairo: Dār al-Hadīth, 2005).

Ibn Badrān, 'Abd al-Qādir, al-Madkhal ilā Madhhab al-Imām Aḥmad ibn Hanbal (Beirut: Mu'assasat al-Risālah, 1991).

Ibn Qudāmah, Shams al-Dīn 'Abd al-Raḥmān, al-Sharh al-Kabīr with alMughnī (Cairo: Dār al-Hadīth, 2004).

Ibn Rushd, Bidāyat al-Mujtahid (Beirut: Dār al-Kutub al-'Ilmiyyah, 2003).

Al-Kāsānī, 'Alā al-Dīn Abū Bakr, Badā'i ' al-Șanā'i' fì Tartīb al-Sharā'i ' (Cairo: Dār al-Hadīth, 2005).

Al-Kharshī, Muhammad Ibn 'Abd Allāh, Sharḥ al-Kharshī 'alā Mukhtaṣar Khalīl (Beirūt: Dār al-Kutub al-'Ilmiyyah, 1997).

Al-Khalīlī, Aḥmad Ibn Hamd, Fatāwā al-Mu'āmalāt (Oman: al-Ajyāl li alTaswīq, 2003).

Al-Majallah (Beirūt: al-Maṭba'at al-Adabiyyah, 1302AH).

Al-Mardāwī, 'Alā al-Dīn, al-Inșāf fì Ma'rifat al-Rājịh min al-Khilāf 'alā Madhhab al-Imām Ahmad Ibn Hanbal (Beirūt: Dār al-Kutub al'Ilmiyyah, 1997).

Ministry of Awqāf and Islamic Affairs, al-Mawsū'ah al-Fiqhiyyah (Kuwait, 1992).

Al-Nawawī, Yaḥyā Ibn Sharaf al-Dīn, Rawụdat al-Ṭālibìn (Cairo: al-Maktabat al-Tawfiqiyyah, 2000).

Al-Nīsābūrī, Abū al-Husayn Muslim Ibn al-Hajjāj, Șah̄ịh Muslim (Beirūt: Dār al-Kutub al-'Ilmiyyah, 2003).

Al-Qalīyūbī wa 'Amīrah, Shihāb al-Dīn, Hāshiyat al-Qalīyūbì wa 'Amīrah (Beirut: Dār al-Kutub al-' Ilmiyyah, 2003).

Al-Qarāfī, Shihāb al-Dīn, Sharh Tanqīh al-Fuṣūl (Cairo: Maktabat al-Kulliyyāt al-Azhariyyah, 1993).

Al-Ramlī, Shams al-Dīn Muḥammad Ibn Aḥmad, Nihāyat al-Muḥtāj ilā Sharh al-Minhāj (Beirut: Dār al-Kutub al-'Ilmiyyah, 1993).

Al-Sajistānī, Sulaymān Ibn al-Ash'ath, Sunan Abī Dāūd (Beirūt: Dār Ibn Hazm, 1997).

Al-Sarakhs̄̄, Abū Bakr, Ușūl al-Sarakhsī, vol. 2 (Beirūt: Dār al-Kutub al'Ilmiyyah, 2005). 
Al-Shawkānī, Muḥammad Ibn 'Alī, Irshād al-Fuhūl ilā Tahqūq al-Haqq min 'Ilm al-Ușūl (Beirūt: Dār al-Kutub al-'Ilmiyyah, 1999).

Al-Shaybān̄̄, Muhammad Ibn al-Ḥasan, al-Makhārij fì al-Hiyal (Cairo: Maktabat al-Thaqāfah al-Dīniyyah, 1999).

Al-Shīrāzī, Abū Isḥāq, al-Muhadhdhab fì Fiqh al-Imām al-Shāfi ì (Beirūt: Dār al-Kutub al-'Ilmiyyah, 1995).

Al-Tirmidhī, Abū 'Īsā Muhammad Ibn 'Īsā, Sunan al-Tirmidhī (Beirūt: Dār al-Kutub al-'Ilmiyyah, 2000).

Al-Zarkashī, Badr al-Dīn, al-Bahr al-Muhịt fì Ușūl al-Fiqh (Beirūt: Dār alKutub al-'Ilmiyyah, 2000).

Zaydān, 'Abd al-Karīm, al-Wajīz fì Ușūl al-Fiqh (Beirūt: Mu'assasat alRisālah, 1997). 
Jurnal Syariah, Jil. 24, Bil. 3 (2016) 423-444 